\title{
Satisfaction of Malaysian Muslim Tourists With Halal Facilities in Japan
}

Wan Muhammad Wan Sulong, Zaid Mohd Zin, Salina Husain, Mohd Sukki Othman, Muhd Zulkifli Ismail

To Link this Article: http://dx.doi.org/10.6007/IJARBSS/v11-i11/11687

DOI:10.6007/IJARBSS/v11-i11/11687

Received: 13 September 2021, Revised: 16 October 2021, Accepted: 30 October 2021

Published Online: 19 November 2021

In-Text Citation: (Sulong et al., 2021)

To Cite this Article: Sulong, W. M. W., Zin, Z. M., Husain, S., Othman, M. S., \& Ismail, M. Z. (2021). Satisfaction of Malaysian Muslim Tourists With Halal Facilities in Japan. International Journal of Academic Research in Business and Social Sciences, 11(11), $2410-2422$.

\section{Copyright: (c) 2021 The Author(s)}

Published by Human Resource Management Academic Research Society (www.hrmars.com)

This article is published under the Creative Commons Attribution (CC BY 4.0) license. Anyone may reproduce, distribute, translate and create derivative works of this article (for both commercial and non0-commercial purposes), subject to full attribution to the original publication and authors. The full terms of this license may be seen at: http://creativecommons.org/licences/by/4.0/legalcode

Vol. 11, No. 11, 2021, Pg. $2410-2422$

Full Terms \& Conditions of access and use can be found at http://hrmars.com/index.php/pages/detail/publication-ethics 


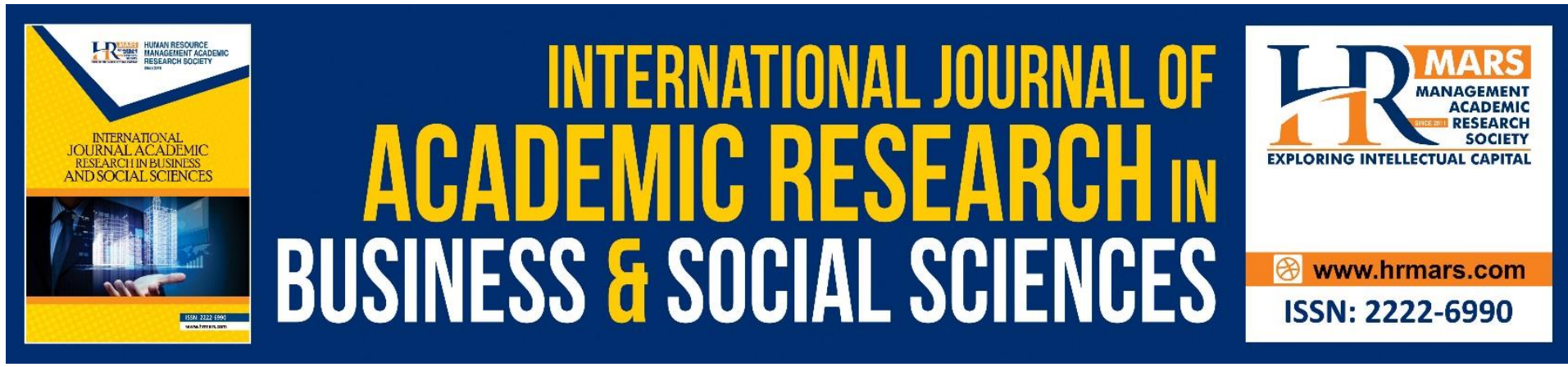

\title{
Satisfaction of Malaysian Muslim Tourists With Halal Facilities in Japan
}

\author{
Wan Muhammad Wan Sulong, Zaid Mohd Zin, Salina Husain, \\ Mohd Sukki Othman, Muhd Zulkifli Ismail \\ Faculty of Modern Languages and Communication, Universiti Putra Malaysia \\ Email:w_mhd@upm.edu.my, zaidmz@upm.edu.my, linahusain@upm.edu.my, \\ msukki@upm.edu.my, zulismail@upm.edu.my
}

\begin{abstract}
Due to the rapid growth of the Muslim population, Halal or Islamic tourism is a market segment that is constantly increasing not only in Muslim countries but also globally. Japan is one of the forefront countries that are becoming more welcoming to Muslim customers. A combination of halal-friendly products and services, as well as omotenashi (traditional Japanese hospitality), is attracting visitors from Muslim countries, including Malaysia. The purpose of this study is to determine the level of satisfaction of Malaysian Muslim tourists with halal facilities based on their visit to Japan. Surveys and questionnaires were utilised to collect data from a total of 288 respondents. Respondents are particularly concerned about the availability of halal facilities to meet religious needs, according to the study's findings. They like the cleanliness of the prayer space at the airport, as well as the amenities gave, such as ablution areas, prayer direction (Qibla), and a prayer rug. They were extremely pleased with the mosque's cleanliness and facilities. On the other hand, they are dissatisfied with the prayer facilities available at tourist destinations because only a small percentage of them provide a prayer room for Muslims. The practice of prayer in public places, on the other hand, is not interrupted or restricted. In regards to accommodations, they believe it is clean and suited for prayer. However, because there is no Qibla direction in the room, no prayer facilities, no halal cuisine, and no prayer time information supplied at the counter, the majority of the accommodations are not very accommodating to Muslim demands.
\end{abstract}

Keywords: Halal Tourism, Prayer facilities, Halal accommodation, Muslim-friendly Tourism, Japan

\section{Introduction}

Halal tourism, which adheres to Islamic principles, is gaining popularity around the world, particularly among Muslim consumers (Mohsin et al., 2016). Muslims are encouraged to travel to observe Allah's beautiful creation in nature and meditate on the goodness of Allah's abundant gifts on humanity. Every region is distinct and offers a variety of attractions. Not only were beautiful mountain ranges, rivers, and lakes provided, but also ethnicity, culture, and customs (Hasanah\& Harun, 2020). 
As the number of Muslim visitors visiting Japan grows, so does the availability of Halal food. However, although facing an increasing impediment in their domestic market, Japanese companies' participation in this area remains low in comparison to other global participants. The Halal tourism business now holds the key to a larger worldwide market, forcing Japanese businesses to view it as a strategic lever for repositioning efforts to join this new market. As such, this study seeks to investigate how satisfied Malaysian Muslim travelers are with halal tourism facilities in Japan during their visits and stays there, particularly in regards to prayer facilities and accommodation. That is, the objectives of this study are:

i. to identify the level of satisfaction with prayer and accommodation facilities in Japan among Malaysian Muslim tourists, and;

ii. to identify factors that lead to the satisfaction feeling towards those facilities among Malaysian Muslim tourists.

\section{Halal Tourism Facilities}

Halal or Islamic tourism is a rapidly increasing market area not only in Muslim nations but around the world. This is owing to the Muslim community's rapid expansion, which is predicted to reach 26.5 percent of the global population by 2030. The majority of Muslims are from some of the world's fastest-growing economies, including Indonesia, Malaysia, Turkey, and the Gulf states. Muslims have evolved into a significant consumer market for the rest of the globe. They will become a more essential section for organisations in all industries. (Global Muslim Travel Index, 2015).

"Halal" refers to what is permissible under Islamic law (CAP, 2006). When it comes to Halal, most people think of it as something related to food. Nonetheless, Halal takes into account a wide range of factors, including purchase intent, source of income, attitude toward advertisement, attitude toward the product, word of mouth, and religiousity (Sulong et al., 2020).

Japan is restructuring its tourist industry to better serve the specific needs of Muslims to attract more Muslim visitors. To meet the growing demand for Halal facilities, Japan has been upgrading its prayer facilities, Halal food availability, and other Muslim travel-related services. Local businesses and firms in Japan are gradually shifting their approach to cater to the Muslim travel market as awareness grows. To cater to Muslim students, more universities in Japan are introducing Halal food. The Japanese government intends to increase the number of foreign students visiting Japan for education by providing better food facilities for Muslim students. Over 7,000 Muslim students are currently studying in Japan, and the number is expected to grow as facilities become more readily available (CrescentRating, 2018).

Halal tourism is gaining attention from researchers recently due to the booming halal market and the increasing Muslim population all over the world. According to Sulong et al (2020), the satisfaction among Malaysian Muslim tourists toward halal food facilities in Japan is fairly high. However, more efforts are needed to enhance the quality of services offered to the Muslim clients such as providing more halal menus, encouraging halal food operators to obtain halal certificates, and providing information required by Muslim tourists such as halal food, prayer time, and Qibla direction at the hotel counters and tourist information centers. In 2013, Khalilur Rahman conducted a study in Malaysia on the motivating factors of Islamic tourists' destination loyalty to assess the effect of tourist motivation on Islamic tourists' satisfaction and destination loyalty. A total of 198 international tourists from various countries who were visiting Malaysia responded to the questionnaires provided. According to the findings, Islamic attributes and quality of service have a significant relationship to Islamic 
tourist satisfaction and destination loyalty, whereas destination attributes have no significant impact on it.

Battour and Ismail (2014) investigated the relationship between tourism motivations and visitor satisfaction, as well as how religion influences the relationship. Tourist satisfaction is considerably and positively associated with tourism motivations, according to the findings. Religion appears to modulate the association between pull motivation and tourist satisfaction, according to the findings.

From the standpoint of industry providers, Marzuki (2012) believes that halal certification provides certain benefits in terms of market signal, Islamic qualities, and marketing aspects, but there are also some costs and compliance difficulties that local authorities must solve. The findings also suggest that halal restaurant meals may appeal to people who aren't religious, bolstering Malaysia's status as a tourism destination and a global halal market hub.

\section{Methodology}

A questionnaire was employed as a survey instrument in this investigation. The questionnaire is bilingual, including English and Malay versions, and it is divided into numerous sections. This article concentrates on demographic data, the prayer facilities section, which has 13 items, and the accommodation section, which has 7 items. In the questionnaire, a five-point Likert scale ranging from "strongly disagree" to "strongly agree" is used. In which, the respondents are required to state their agreement level by selecting on the scale ranging from 1 to 5 , whereas from strongly disagree to strongly agree respectively.

In terms of sampling, this study uses a convenient sampling procedure to conduct a survey. Before the questionnaire was distributed, the participants were told of the study's purpose. A total of 288 questionnaires were chosen for review. The IBM SPSS version 25 program was used to analyse the data, which included descriptive analysis to define the features of the variables using the mean, standard deviation, frequency, and percentage, as well as drawing conclusions based on numerical data (Ghazali \& Sufean, 2016).

\section{Findings \\ Demographic Profile}

To achieve the current study's objectives, it is necessary to assess the characteristics of the participants. The participants' age was a significant demographic aspect derived from the participants. This analysis revealed that respondents between the ages of 18 and 30 made up the majority of the sample (66.3\%), while those between the ages of 51 and 60 made up only $3.5 \%$.

Malaysian Muslims could come from a variety of ethnic backgrounds, therefore the participants' race was also noted. According to the findings, Malay Muslims made up $95.5 \%$ of the participants, while Chinese Muslims made up only $2.8 \%$. A large number of individuals (estimated at 9.4\%) visited Japan for travel/leisure purposes, whereas 28.1 percent went to study. Between 2013 and 2017, a high percentage of the participants (81.3\%) visited Japan, with the majority staying for less than one month (83.3\%).

Tokyo was also selected by the participants as the most visited place during their travel to Japan, as indicated by the fact that $49 \%$ of the respondents chose the city. The cities of Osaka, Kyoto, and Kobe garnered the second-highest percentage of votes (22.6\%), followed by Fukuoka and Nagasaki (13.5\%). Hotels were the most prevalent kind of lodging accessible to the participants throughout their visit, according to the participants. In terms of Japanese proficiency, $71.9 \%$ reported being unable to communicate in Japanese. 


\section{Descriptive Analysis}

The means and standard deviation of the responses were used to describe the datasets used for both aspects (see table 1). The prayer facilities received a higher mean score (3.47). Accommodation scored the least (2.69) showing that the respondents did not appreciate it during their visit to Japan. These findings are reliable since the standard deviation values for all the components were below one. Therefore, illustrating most of the value responses are less spread above and below the mean making their analysis reliable.

Table 1: Descriptive Analysis

\begin{tabular}{lcc}
\hline Variables & Mean & SD \\
\hline Prayer Facilities & 3.47 & 0.61 \\
Accommodation & 2.69 & 0.76
\end{tabular}

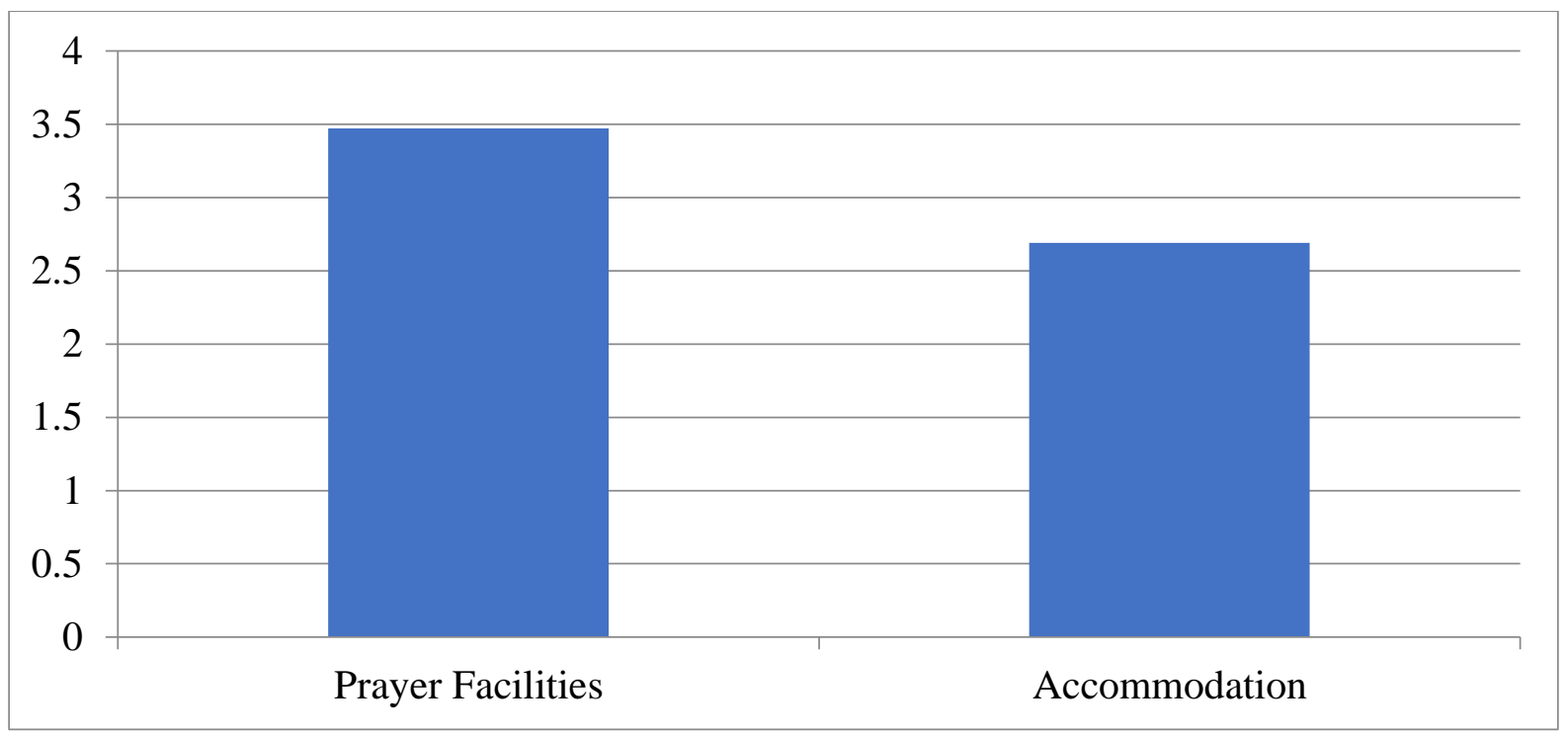

Figure 1: Descriptive analysis summary for both aspects

\section{Prayer Facilities}

Tourism and religion have a unique relationship, one that is characterized by competition and mutual influence. According to Weidenfeld and Ron (2008), the two can work in a complementary manner thus garnering mutual influence on people while serving their religious needs while on tours. In Japan, tourists have access to prayer facilities to use whenever the need arises during travel. On average, a substantial number of people find it challenging to get a place to perform prayers in Japan ( $A 1, x=2.97 \pm 1.13$ ). The mean was closest to 3 suggesting that almost equal numbers of people agreed and disagreed on this assertion. Regardless, airports ( $22, x=3.95 \pm 1.08)$ and hotels $(A 7, x=3.09 \pm 1.06)$ in Japan have prayer facilities that are comfortable and clean to use. As a feature of hospitality in Japan, centers have adequate prayer facilities to ensure a positive experience. According to the survey, the ablutions at the airport $(A 3, x=3.89 \pm 1.13)$ and Halal restaurants $(A 8, x=3.09)$ are both clean and comfortable. As such, people can relax while using the prayer facilities in Japan. Additionally, women are provided with a head covering whenever they need it while using the prayer rooms $(A 5, x=3.10 \pm 1.05)$. A "Telekung" is the term given to the cloth women use to cover the head and face during prayer sessions. Further facilities such as a prayer rug are available at airports' prayer rooms $(A 4, x=3.47 \pm 1.10)$ allowing tourists to feel comfortable while visiting and experiencing new people and culture. [See Table 2]. 
Moreover, the facilities inland are even more impressive as the analysis of the survey participation reveals. $A$ considerable number of the participants $(A 1, S=27.4 \%)$ believe that it is easy to locate a prayer place while in Japan. The mosques, for instance, are regarded to have comfortable and well-equipped prayer facilities ( $A 9, x=3.82 \pm 1.07$ ). More than half of the participants' population $(A 9, A=29.5 \%$, and $S A=33.0 \%)$ agree with this assertion. Further, the facilities offer privacy allowing users to perform personal prayers at public locations (A10, $x=3.82 \pm 0.94)$, as $64.9 \%$ of the participants agree $(A=38.9 \%, S A=26.0 \%)$. [See Table 2].

In Japan, prayer facilities are not limited to airports, hotels, and religious places. According to this study's survey, tourists are free to use the prayer facilities at learning institutions (A12, $x=3.37 \pm 0.91)$ which were identified as comfortable and sufficient ( $A 11, x=3.52 \pm 0.93)$. As it stands, most of the participants ( $A 12, N=45.1 \%$ ) demonstrated unfamiliarity to this notion but an equally large fraction ( $\mathrm{A} 12, \mathrm{~A} / \mathrm{SA}=42 \%$ ) seemed to have experienced the hospitality of Japan's prayer houses. A significantly large portion of the tourist participants of this study also demonstrated that the prayer facilities are not only convenient but also provide pleasure and satisfaction $(A 13, x=4.14 \pm 0.98)$. The results depict that $44.4 \%(S A)$ strongly agree with this position complemented by another $34 \%$ who agree[See Table 2]. Only $7 \%$ disagreed with the quality of Japan's prayer facilities when it comes to convenience or comfortability. In this sense, Japan has substantial Islamic prayer facilities and is thus a good tourist site for Muslims. This is supported by the fact that the country has adequate prayer facilities and accessories at airports and hotels, let alone public mosques that would be suitable for visiting Muslims. 
Table 2: Prayer Facilities Descriptive Analysis

\begin{tabular}{|c|c|c|c|c|c|c|c|c|}
\hline Item & Statement & SDA & DA & $\mathbf{N}$ & A & SA & Mean & SD \\
\hline A1 & $\begin{array}{l}\text { It's easy for me to get a } \\
\text { place to perform prayer } \\
\text { in Japan. }\end{array}$ & $\begin{array}{c}26 \\
(9.0)\end{array}$ & $\begin{array}{c}86 \\
(29.9)\end{array}$ & $\begin{array}{c}72 \\
(25.0)\end{array}$ & $\begin{array}{c}79 \\
(27.4)\end{array}$ & $\begin{array}{c}25 \\
(8.7)\end{array}$ & 2.97 & 1.13 \\
\hline $\mathrm{A} 2$ & $\begin{array}{l}\text { The prayer area at the } \\
\text { airport is comfortable } \\
\text { and clean. }\end{array}$ & $\begin{array}{c}12 \\
(4.2)\end{array}$ & $\begin{array}{c}14 \\
(4.9)\end{array}$ & $\begin{array}{c}60 \\
(20.8)\end{array}$ & $\begin{array}{c}91 \\
(31.6)\end{array}$ & $\begin{array}{c}111 \\
(38.5)\end{array}$ & 3.95 & 1.08 \\
\hline A3 & $\begin{array}{l}\text { The ablution area at the } \\
\text { airport is comfortable } \\
\text { and clean. }\end{array}$ & $\begin{array}{c}14 \\
(4.9)\end{array}$ & $\begin{array}{c}18 \\
(6.3)\end{array}$ & $\begin{array}{c}61 \\
(21.2)\end{array}$ & $\begin{array}{c}87 \\
(30.2)\end{array}$ & $\begin{array}{c}108 \\
(37.5)\end{array}$ & 3.89 & 1.13 \\
\hline A4 & $\begin{array}{l}\text { Prayer rug is available at } \\
\text { the airport's prayer } \\
\text { room. }\end{array}$ & $\begin{array}{c}10 \\
(3.5)\end{array}$ & $\begin{array}{c}47 \\
(16.3)\end{array}$ & $\begin{array}{c}89 \\
(30.9)\end{array}$ & $\begin{array}{c}81 \\
(28.1)\end{array}$ & $\begin{array}{c}61 \\
(21.2)\end{array}$ & 3.47 & 1.10 \\
\hline A5 & $\begin{array}{l}\text { Telekung is provided at } \\
\text { the airport's prayer } \\
\text { room. }\end{array}$ & $\begin{array}{c}21 \\
(7.3)\end{array}$ & $\begin{array}{c}49 \\
(17.0)\end{array}$ & $\begin{array}{c}131 \\
(45.5)\end{array}$ & $\begin{array}{c}53 \\
(18.4)\end{array}$ & $\begin{array}{c}34 \\
(11.8)\end{array}$ & 3.10 & 1.05 \\
\hline A6 & $\begin{array}{l}\text { It is easy to get a place to } \\
\text { perform prayer at tourist } \\
\text { locations. }\end{array}$ & $\begin{array}{c}28 \\
(9.7)\end{array}$ & $\begin{array}{c}92 \\
(31.9)\end{array}$ & $\begin{array}{c}79 \\
(27.4)\end{array}$ & $\begin{array}{c}72 \\
(25.0)\end{array}$ & $\begin{array}{c}17 \\
(5.9)\end{array}$ & 2.85 & 1.09 \\
\hline A7 & $\begin{array}{l}\text { Prayer areas at the halal } \\
\text { restaurants visited are } \\
\text { suitable and comfortable. }\end{array}$ & $\begin{array}{c}21 \\
(7.3)\end{array}$ & $\begin{array}{c}63 \\
(21.9)\end{array}$ & $\begin{array}{c}98 \\
(34.0)\end{array}$ & $\begin{array}{c}82 \\
(28.5)\end{array}$ & $\begin{array}{c}24 \\
(8.3)\end{array}$ & 3.09 & 1.06 \\
\hline A8 & $\begin{array}{l}\text { Ablution areas at the } \\
\text { halal restaurants visited } \\
\text { are comfortable. }\end{array}$ & $\begin{array}{c}21 \\
(7.3)\end{array}$ & $\begin{array}{c}56 \\
(19.4)\end{array}$ & $\begin{array}{c}110 \\
(38.2)\end{array}$ & $\begin{array}{c}78 \\
(27.1)\end{array}$ & $\begin{array}{c}23 \\
(8.0)\end{array}$ & 3.09 & 1.04 \\
\hline A9 & $\begin{array}{l}\text { Prayer facilities at } \\
\text { mosques are comfortable } \\
\text { and well-equipped. }\end{array}$ & $\begin{array}{c}8 \\
(2.8)\end{array}$ & $\begin{array}{c}23 \\
(8.0)\end{array}$ & $\begin{array}{c}77 \\
(26.7)\end{array}$ & $\begin{array}{c}85 \\
(29.5)\end{array}$ & $\begin{array}{c}95 \\
(33.0)\end{array}$ & 3.82 & 1.07 \\
\hline A10 & $\begin{array}{l}\text { No interruption or } \\
\text { restriction for me to } \\
\text { perform prayer in public } \\
\text { locations. }\end{array}$ & $\begin{array}{c}4 \\
(1.4)\end{array}$ & $\begin{array}{c}18 \\
(6.3)\end{array}$ & $\begin{array}{c}79 \\
(27.4)\end{array}$ & $\begin{array}{c}112 \\
(38.9)\end{array}$ & $\begin{array}{c}75 \\
(26.0)\end{array}$ & 3.82 & 0.94 \\
\hline A11 & $\begin{array}{l}\text { I could easily perform } \\
\text { prayer at the higher } \\
\text { learning institutions. }\end{array}$ & $\begin{array}{c}4 \\
(1.4)\end{array}$ & $\begin{array}{c}26 \\
(9.0)\end{array}$ & $\begin{array}{c}122 \\
(42.4)\end{array}$ & $\begin{array}{c}87 \\
(30.2)\end{array}$ & $\begin{array}{c}49 \\
(17.0)\end{array}$ & 3.52 & 0.93 \\
\hline A12 & $\begin{array}{l}\text { Prayer facilities at higher } \\
\text { learning institutions are } \\
\text { comfortable and good. }\end{array}$ & $\begin{array}{c}8 \\
(2.8)\end{array}$ & $\begin{array}{c}29 \\
(10.1)\end{array}$ & $\begin{array}{c}130 \\
(45.1)\end{array}$ & $\begin{array}{c}89 \\
(30.9)\end{array}$ & $\begin{array}{c}32 \\
(11.1)\end{array}$ & 3.37 & 0.91 \\
\hline A13 & $\begin{array}{l}\text { The convenience of } \\
\text { performing prayer gives } \\
\text { more pleasure and } \\
\text { satisfaction when } \\
\text { traveling in Japan. }\end{array}$ & $\begin{array}{c}6 \\
(2.1)\end{array}$ & $\begin{array}{c}14 \\
(4.9)\end{array}$ & $\begin{array}{c}42 \\
(14.6)\end{array}$ & $\begin{array}{c}98 \\
(34.0)\end{array}$ & $\begin{array}{c}128 \\
(44.4)\end{array}$ & 4.14 & 0.98 \\
\hline & Overall & & & & & & 3.47 & 0.61 \\
\hline
\end{tabular}




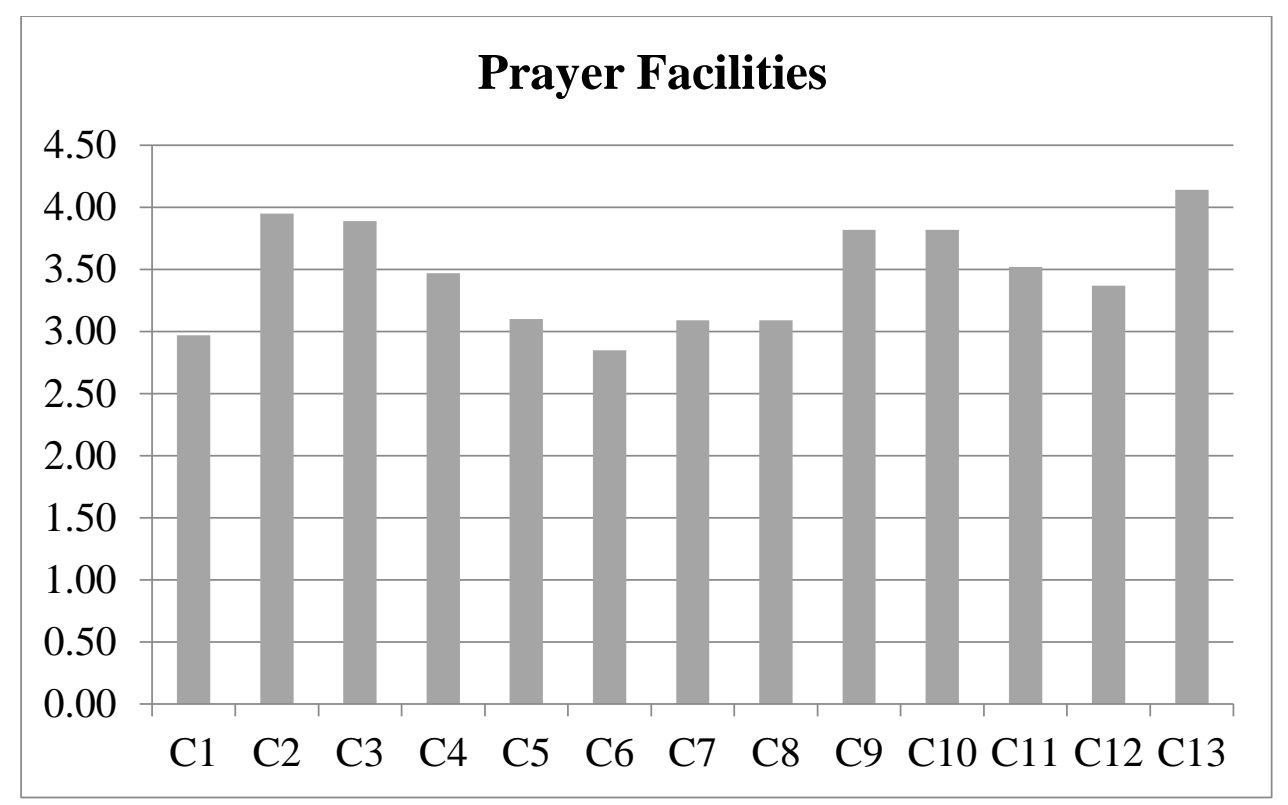

Figure 2: Prayer facilities descriptive analysis

\section{Accommodation}

When it comes to quality accommodation, several aspects are considered in Japan's hospitality. Tourists, for one, are provided with rooms for stay depending on the duration. The rooms are kept and maintained at conditions aiming to provide the best experience for tourists $(B 5, x=4.01 \pm 1.13)$. The high mean score suggests that most of the participants agreed with this claim. In particular, $40.6 \%$ strongly agreed and $37.2 \%$ agreed compared to the measly $11.2 \%$ disagreeing. In addition to clean rooms, the accommodation service also provides food but with few locations providing Halal menus ( $B 6, x=2.68 \pm 1.08$ ). This is a disadvantage for Muslim tourists who adhere to their religious laws. In particular, Henderson (2016) postulate that Muslims consume Halal food which is the same as permitted under Islamic law. For example, any animal or poultry killed in a manner that does not adhere to the Koran's teachings is not fit for consumption. As an intervention for Muslims with little to no access to Halal menus can still use the in-room cooking facilities that are available at most accommodations (B7, $x=3.28 \pm 1.34$ )[See Table 3]. In this way, anyone with special conditions for feeding can do so without restrictions.

In most places, the conditions of the accommodations for tourists are customized to give the best experience possible. For the Muslim individuals vising Japan, a prayer rug is not provided in the accommodation room $(B 2, x=2.21 \pm 1.12)$ in most locales. This is evidenced by the many disagreeing parties (SDA $=30.9 \%, D A=36.8 \%)$ compared to the agreeing ones $(A=11.1 \%$, $\mathrm{SA}=4.2 \%$ ). Furthermore, a Qibla compass is also not provided in the rooms for tourists ( $\mathrm{B} 1$, $\mathrm{x}=2.29 \pm 1.17$ ). This is an instrument that the Islamic community uses to tell the direction to face while performing prayers. The compass points are said to point in the direction of the city of Mecca which is of great importance to Muslims. In addition, the accommodation facilities do not provide a Quran for individuals to use (B3, $x=2.05 \pm 1.07$ ). Most of the participants $(B 3, \mathrm{SDA}=35.8 \%, \mathrm{DA}=39.2 \%$ ) point out that the accommodation facilities do not provide such a specific item for the tourist's comfort. Additionally, prayer information is not easily obtained from the information desk (B4, $x=2.34 \pm 1.05)$. [See Table 3].

What stands out is the fact that Halal accommodations are not common in Japan. The facilities are lacking in all the elements that would make a Muslim tourist comfortable. The survey reveals that things like a Qibla compass, prayer rugs, Quran, and prayer information are not 
provided at accommodation sites. This means that Japan has low scores in terms of Halal accommodation.

Table 3: Halal accommodation descriptive analysis

\begin{tabular}{|c|c|c|c|c|c|c|c|c|}
\hline Item & Statement & SDA & DA & $\mathbf{N}$ & A & SA & Mean & SD \\
\hline B1 & $\begin{array}{l}\text { Qibla direction is provided } \\
\text { in the accommodation } \\
\text { room. }\end{array}$ & $\begin{array}{c}91 \\
(31.6)\end{array}$ & $\begin{array}{c}85 \\
(29.5)\end{array}$ & $\begin{array}{c}63 \\
(21.9)\end{array}$ & $\begin{array}{c}36 \\
(12.5)\end{array}$ & $\begin{array}{c}13 \\
(4.5)\end{array}$ & 2.29 & 1.17 \\
\hline B2 & $\begin{array}{l}\text { Prayer rug is provided in } \\
\text { the accommodation room. }\end{array}$ & $\begin{array}{c}89 \\
(30.9)\end{array}$ & $\begin{array}{c}106 \\
(36.8)\end{array}$ & $\begin{array}{c}49 \\
(17.0)\end{array}$ & $\begin{array}{c}32 \\
(11.1)\end{array}$ & $\begin{array}{c}12 \\
(4.2)\end{array}$ & 2.21 & 1.12 \\
\hline B3 & $\begin{array}{l}\text { Al-Quran is provided in the } \\
\text { accommodation room. }\end{array}$ & $\begin{array}{c}103 \\
(35.8)\end{array}$ & $\begin{array}{c}113 \\
(39.2)\end{array}$ & $\begin{array}{c}38 \\
(13.2)\end{array}$ & $\begin{array}{c}24 \\
(8.3)\end{array}$ & $\begin{array}{c}10 \\
(3.5)\end{array}$ & 2.05 & 1.07 \\
\hline B4 & $\begin{array}{l}\text { Prayer time information is } \\
\text { easily obtainable through } \\
\text { the counter in } \\
\text { accommodation. }\end{array}$ & $\begin{array}{c}69 \\
(24.0)\end{array}$ & $\begin{array}{c}98 \\
(34.0)\end{array}$ & $\begin{array}{c}84 \\
(29.2)\end{array}$ & $\begin{array}{c}27 \\
(9.4)\end{array}$ & $\begin{array}{c}10 \\
(3.5)\end{array}$ & 2.34 & 1.05 \\
\hline B5 & $\begin{array}{l}\text { The room is clean and } \\
\text { suitable for praying. }\end{array}$ & $\begin{array}{c}18 \\
(6.3)\end{array}$ & $\begin{array}{c}14 \\
(4.9)\end{array}$ & $\begin{array}{c}32 \\
(11.1)\end{array}$ & $\begin{array}{c}107 \\
(37.2)\end{array}$ & $\begin{array}{c}117 \\
(40.6)\end{array}$ & 4.01 & 1.13 \\
\hline B6 & $\begin{array}{l}\text { Halal menus are provided } \\
\text { at the accommodation. }\end{array}$ & $\begin{array}{c}44 \\
(15.3)\end{array}$ & $\begin{array}{c}81 \\
(28.1)\end{array}$ & $\begin{array}{c}103 \\
(35.8)\end{array}$ & $\begin{array}{c}44 \\
(15.3)\end{array}$ & $\begin{array}{c}16 \\
(5.6)\end{array}$ & 2.68 & 1.08 \\
\hline B7 & $\begin{array}{l}\text { There is an in-room } \\
\text { cooking facility at the } \\
\text { accommodation. }\end{array}$ & $\begin{array}{c}37 \\
(12.8)\end{array}$ & $\begin{array}{c}51 \\
(17.7)\end{array}$ & $\begin{array}{c}59 \\
(20.5)\end{array}$ & $\begin{array}{c}76 \\
(26.4)\end{array}$ & $\begin{array}{c}65 \\
(22.6)\end{array}$ & 3.28 & 1.34 \\
\hline & Overall & & & & & & 2.69 & 0.76 \\
\hline
\end{tabular}

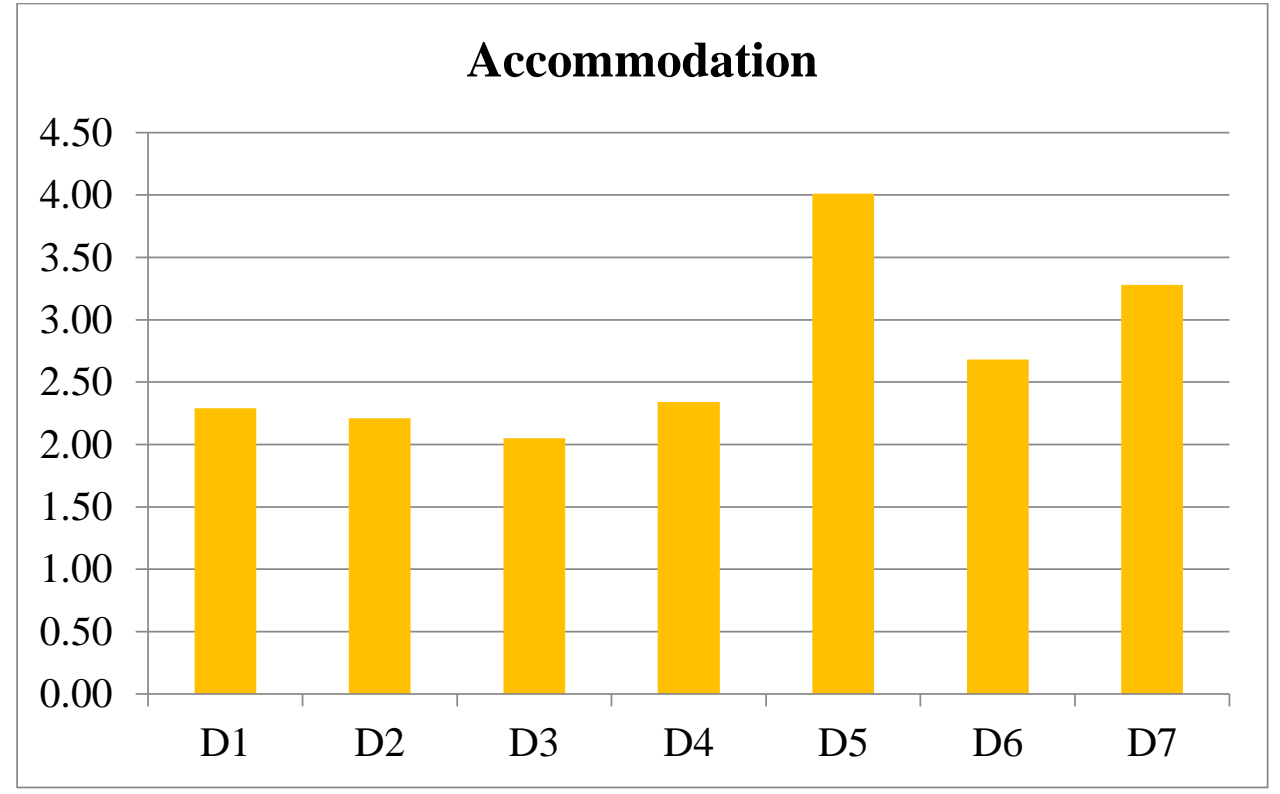

Figure 3: Halal accommodation descriptive analysis

\section{Level of Satisfaction}

This section of the report will describe the respondents' levels of satisfaction concerning prayer facilities, accommodations, and communication. The responses were divided into three categories: low (1-2.33), moderate (2.34-3.67), and high (3.68-5.00). In the tables, the 
frequency indicates the number of participants who chose the option (level of satisfaction), whereas the percentage indicates the proportion of participants who chose each level.

\section{Prayer Facilities}

The survey participants asserted that the prayer facilities are moderately satisfying $(57.6 \%)$. Also, $38.2 \%$ of the respondents pointed out that the facilities were satisfactory which is significantly higher than the $4.2 \%$ who think otherwise (see table 4 ).

Table 4: The level of satisfaction on prayer facilities

\begin{tabular}{ccc}
\hline Prayer facilities & Frequency & Percent \\
\hline Low & 12 & 4.2 \\
Moderate & 166 & 57.6 \\
High & 110 & 38.2 \\
Total & $\mathbf{2 8 8}$ & $\mathbf{1 0 0 . 0}$ \\
\hline
\end{tabular}

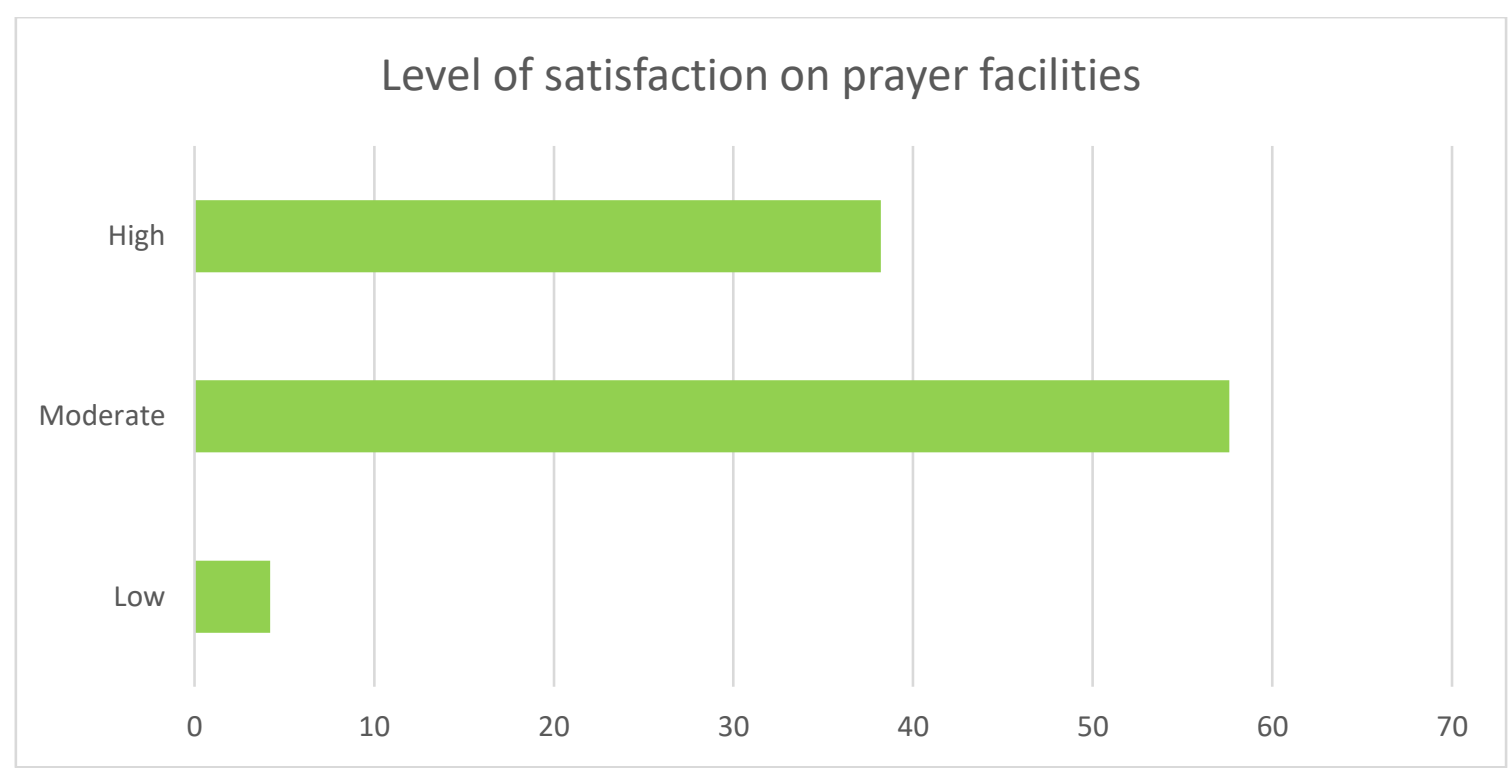

\section{Accommodation}

Figure 4: The level of satisfaction on prayer facilities

The quality of accommodation will also influence the level of satisfaction of the Malaysian Muslim tourists as they visit Japan which makes this a vital dimension to consider. Since shelter is a basic need, the accommodation of the tourists comprises one of the fundamental requirements for the service providers. The table below shows that the largest percentage of the respondents (55.6\%) rated the accommodation services available to Muslim tourists in Japan as moderate.

Table 5: The level of satisfaction on accommodation

\begin{tabular}{lll}
\hline Accomodation & Frequency & Percent \\
\hline Low & 95 & 33.0 \\
Moderate & 160 & 55.6 \\
High & 33 & 11.5 \\
Total & $\mathbf{2 8 8}$ & $\mathbf{1 0 0 . 0}$ \\
\hline
\end{tabular}




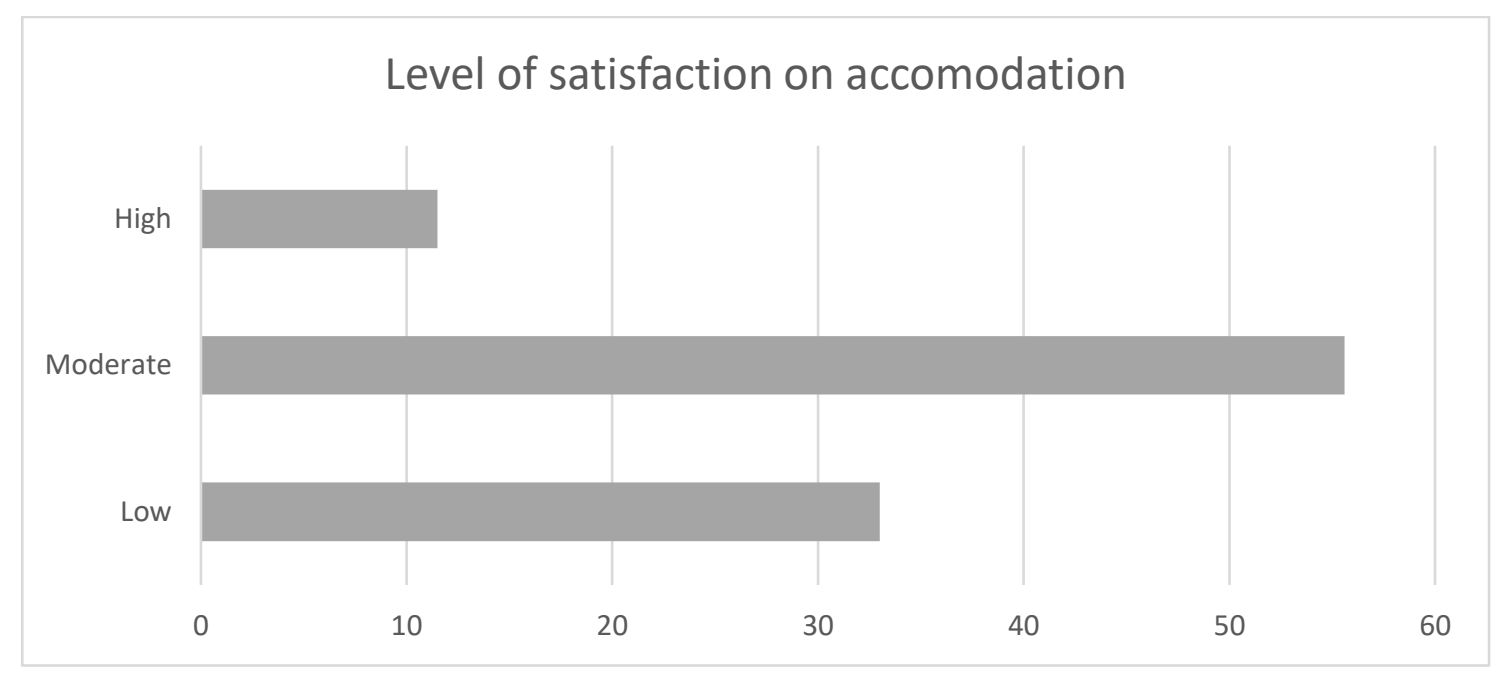

Figure 5: The level of satisfaction with accommodation

\section{Conclusion}

As far as service quality is concerned, Teshnizi et al. (2018) note that the appearance of the facilities, personnel, communication technology, and equipment are only part of a whole. Other determinants, such as responsiveness, assurance, reliability, and empathy are valuable considerations for service quality. Furthermore, these dimensions are not equal with stronger emphasis placed on reliable, responsive, assured, empathetic, and tangible services, consecutively. Based on the findings of this study, prayer facilities in Japan are not only tangible but also quite reliable and assuring. An individual has access not only to the prayer facilities but also to the ablution and other essentials for prayer sessions. On another note, the prayer and ablution facilities are well maintained and clean, thus appealing for use. Individuals seeking to make scheduled prayers have access to prayer rugs suggesting empathy on their part. Muslims' prayer involves positions that cause the knee to touch the floor. Rugs serve to keep people clean during and after the prayer. This show of concern for the customer's welfare and comfort creates a suitable atmosphere for Halal tourism.

Japan is a nation experiencing a rapid rate of growth, especially in recent years. That means that it is expected that its commodities are to be of high quality. However, the fact that many of the respondents highlight the Japanese accommodation facilities as moderate could be an outcome of the fact that they were not designed with the needs of Muslims primarily. The Islamic religion has its set of practices that its supporters hold rather dear. Therefore, having accommodation facilities that do not meet the required standards could be rather challenging for Muslim tourists. This position could also explain why $33 \%$ of the respondents rated their satisfaction as low. These participants may have felt that the accommodation facilities do not meet their cultural needs. Since these facilities were designed with a multicultural perspective in mind, some of the Muslim tourists may find it difficult to use the accommodation facilities leading to a poor experience. Therefore, these findings demonstrate how the quality of these facilities can influence the future intention of Muslim tourists to visit the country once more.

\section{Acknowledgement}

This work was supported by The Sumitomo Foundation, Fiscal 2015 Grant For Japan-Related Research Projects. 


\section{References}

CAP, Consumers Association of Penang. (2006) Halal and Haram: An important Book for Muslim Consumers. Pulau Pinang Malaysia: CAP

CrescentRating. (2018). Global Muslim Travel Index 2018 (GMTI 2018). Singapore: Mastercard Asia Pacific Pte. Ltd.

CrescentRating. (2015). Japan Welcomes halal tourism. Retrieved from http://www.crescentrating.com/blog/item/3658-japan-welcomes-halal-tourism.html on October 222020

Eid, R., \& El-Gohary, H. (2015). The role of Islamic religiosity on the relationship between perceived value and tourist satisfaction. Tourism Management, 46, 477-488

Darusalam, G., \& Hussin, S. (2016). Metodologi penyelidikan dalam pendidikan. Kuala Lumpur: Penerbit Universiti Malaya.

Henderson, J. C. (2016). Halal food, certification and halal tourism: Insights from Malaysia and Singapore. Tourism Management Perspectives, 19, 160-164.

Japan Halal Association. (2012). JAKIM recognized certification body in Japan. Retrieved from http://www.jhalal.com/english. Retrieved 23 May 2012.

Kojima H. (2006). Variations in demographic characteristics of foreign Muslim population in Japan: a preliminary estimation. The Japanese Journal of Population. 4(1); 115-130.

McDaniel, S. W., \& Burnett, J. J. (1990). Consumer religiosity and retail store evaluative criteria. Journal of the Academy of Marketing Science, 18, 101-112.

Battour, M., Ismail, M. N. (2014). The role of destination attributes in Islamic Tourism. Retrieved from SHS Web of Conferences 12, 011077 (2014)

Mohsin, A., Ramli, N., \& Alkhulayfi, B. A. (2016). Halal tourism: Emerging opportunities. Tourism Management Perspectives, 19, 137-143. https://doi.org/10.1016/j.tmp.2015.12.010

Rahman, M. K. (2014). Motivating factors of Islamic tourist's destination loyalty: An empirical investigation in Malaysia. Journal of Tourism and Hospitality Management, 2/1, pp. 63-77.

Shakona, M., Backman, K., Backman, S., Norman, W., Luo, Y., \& Duffy, L. (2015). Understanding the traveling behavior of Muslims in the United States. International Journal of Culture, Tourism and Hospitality Research, 9(1), 22-35.

Shazlinda, Yusof, M., Shutto, N. (2014). The Development of halal food market in Japan: An Exploratory Study. Procedia- Social and Behavioral Sciences, 121, 253-261.

Marzuki, S. Z. S. (2012). Understanding Restaurant manager's Expectations of Halal Certification in Malaysia. (Unpublished doctoral thesis). University of Canterbury, New Zealand.

Sulong, W. M. W., Husain, S., Ismail, M. Z., Othman, M. S., Zin, Z. M., Ghazali, R. M. (2020). Halal Food Facilities in Japan from The Perspective of Malaysian Muslim Tourists. International Journal of Academic Research in Business and Social Sciences. 10(11), 180-192.

Hasanah, S., Harun, A. N. (2020). Muslim friendly tourism and western creative tourism: The conceptual intersection analysis. International Journal of Islamic Business Ethics, 5 (1), 21-32

Teshnizi, S. H., Aghamolaei, T., Kahnouji, K., Teshnizi, S. M., \& Ghani, J. (2018). Assessing the quality of health services with the SERVQUAL model in Iran. A systematic review and meta-analysis. International Journal for Quality in Health Care, 30(2), 82-89. 
INTERNATIONAL JOURNAL OF ACADEMIC RESEARCH IN BUSINESS AND SOCIAL SCIENCES

Vol. 11, No. 11, 2021, E-ISSN: 2222-6990 @ 2021 HRMARS

Weidenfeld, A., \& Ron, A. S. (2008). Religious Needs in the Tourism Industry. Anatolia, 19(2), 357-361 